\title{
Performance of Public Mutual Funds (PMFs) in Emerging Economies: A Case of Bangladesh
}

\author{
Md. Rashidul Islam ${ }^{1} \&$ Leo Vashkor Dewri ${ }^{1}$ \\ ${ }^{1}$ East West University, Dhaka, Bangladesh \\ Correspondence: Leo Vashkor Dewri, East West University, Dhaka, Bangladesh. E-mail: \\ leodewri81@gmail.com \\ Received: March 15, 2015 \\ Accepted: April 8, 2016 \\ Online Published: May 25, 2016 \\ doi:10.5539/ijbm.v11n6p296 \\ URL: http://dx.doi.org/10.5539/ijbm.v11n6p296
}

\begin{abstract}
Public Mutual fund (PMF) is an instrument for pooling the funds by issuing units to the investors and investing funds in the capital market to achieve their objectives. To invest in mutual funds is a complicated trade for investors as individual assets are belongs to verity of risks and they are dubious on return on investment. There are only 43 Mutual Funds are available to choose from where the investors can invest. To take the investment decision, the investors need to know which funds are performing better than others, gives more return, which fund is more risky etc. In this study the performance evaluation of public mutual funds carried out by considering fund age, fund size, fund return, fund dividend payout, fund price earnings ratio and fund net asset value (NAV). There are only eight PMFs are available in Bangladesh. For analysis purposes the study investigates 1999 to 2015 operations of PMF. Therefore, this study analyzes 128 a firm years, for measuring PMFs performance. The study reveals that fund size, fund return, fund dividend payout and P/E ratio has significant relation on fund performance. Whereas, fund age and fund NAV has insignificant relation on fund performance.
\end{abstract}

Keywords: public mutual funds, fund performance, management expertise

\section{Introduction}

Bangladesh is one of the least developed countries in the world with minimum natural and financial resources. The development of Bangladesh is being hindered due to lack of insufficient capital. To accelerate the phase of industrialization through the development of capital market and broadening the base of investment, The Investment Corporation of Bangladesh (ICB) was established on 1 October 1976, under "The Investment Corporation of Bangladesh Ordinance, 1976" (No. XL of 1976). The establishment of ICB was a major step in a series of measures undertaken by the Government to accelerate the pace of industrialization and to develop a well-organized and vibrant Capital Market particularly securities market in Bangladesh. Through the enactment of the Investment Corporation of Bangladesh (Amendment) Act, 2000 (no. 24 of 2000), reforms in operational strategies and business policies have been implemented by establishing and operating subsidiary companies with ICB.

Mutual funds defined as means of fund established in the form of a Trust to raise money through the sale of units to the public for investment. These funds offer a way to investors which create verity of investment opportunities. Investors who desire regular income by means of dividends and unwilling to take higher risk prefers to invest in Mutual Funds. Mutual Fund scheme ensures safety of capital, assured regular income, capital appreciation and maximum liquidity through management expertise. For these features Mutual Funds grows rapidly over the tenure.

The performance of PMFs reflect on: management expertise of the funds, fund volume, year of operating experiences, tenure of the fund, as well as considering the securities market segmentation FTSE100, FTSE500, DSEX index, DSES index, DS30 index and so on. Managerial expertise plays a vital role for PMFs performance. Likewise, panel of fund managers are better performer than individual managers (Prather, Middelton, \& Cusack, 2001). Similarly, fund size also has greater impact on fund performance because large funds have greater capability to hold large market share and higher trading volume that leads to lesser spreads on transaction (Glosten \& Harris, 1988). Similarly, transaction cost declines with trading volume (Brennan and Hughes, 1991). The reason is that large transaction generates a discount facilities provided by the brokerage firms. So fund fees 
are also decreased. Younger mutual funds performance generally affected by the investment learning period as limited experience of holding diversified portfolios (Gregory, Matatko, \& Luther, 1997). Younger mutual funds are tend to be underperformer as they are invested in fewer securities with higher market risk (Bauer, Koedijk, \& Otten, 2002). Additionally, the legal environment quality leads to the financial development in country. However, variations of regulatory frame works may influence on the investors' behavior. When rights are not properly protected by the regulation investors feel uncomfortable on their investment decision. As a result of that, investors will be reluctant to invest in markets where their rights are not properly protected. Similarly, those countries have less protection on investment and investors generally hold significantly smaller debt and low capital market investment (Porta et al., 1997).

The objective of this study to investigate the performance of PMFs by analyzing the fund size, fund operational maturity and associated risk, management structure and tenure, investors behaviors and fund manager expertise. To pursue the research this study considers the day-to-day trading record of PMFs through Dhaka and Chittagong Stock Exchange.

\section{Literature Review and Hypothesis Development}

\subsection{Fund Size and Performance}

According to Chen et al. (2004) there are advantages on economic of scale, such as large volume of resources have lower expense ratios. Conversely, opponents believe that a comparatively high asset base corrode fund performance due to trading costs associated with liquidity or price impact (Roger Lowenstein, 1997). Additionally, large fund can be invested in junk portfolios and erode fund performance. On the other hand, a small fund can be poured easily in its best ideas and can invest in the optimal stock, whereas, a large fund cannot. However, there is mixed evidence that fund return decline with fund size (Grinblatt \& Titman, 1989). Needless to say, there is no consensus on this issue.

According to Glosten and Harris (1988) large funds lead to minimum operational cost as these are capable to bargain lesser spreads. In addition, large funds have greater market domination as well as enhanced trading volumes. Moreover, due high market domination and large trade volume these funds enjoy economy of scale over fund operational cost (Brennan \& Hughes, 1991).

Ciccotello and Grant (1996) argue that past returns of big funds are found to be higher than smaller funds. Since the large funds are invested in diversified way and minimizing overall risk of portfolios and gain better financial performance over the period of time. Therefore the first hypothesis we are going to test:

\section{$\mathbf{H}_{1}$ : Fund size related to the performance of the Mutual Fund.}

\subsection{Fund Age and Performance}

Fund age refers to fund's prolonged existence and manager's capability. Generally, the age of funds effects on performance in both directions. However, younger mutual funds are more vigilant and can suffer from their early stages due to this fund face higher costs and lack of experience (Ferreira et al., 2012). Younger mutual funds performance can also be affected during investment learning period due to fund managers lesser experience on fund operations (Gregory, Matatko, \& Luther, 1997).

Gregory, Matatko, and Luther (1997) refer that age of fund plays a significant role on fund performance due to investment learning. It indicates that the aged fund gains comparatively higher return and tend to be larger than younger funds. Bauer, Koedijk, and Otten (2002) also evidence that young mutual funds' are generally more vulnerable in credit ratings due to small fund size and lower in returns. However, younger funds perform better than older funds when the fund manages by the experienced fund manager (Otten \& Bams, 2002) regardless age of the fund. Similarly, emperical studies evidence that there is no association between age and the the mutual fund performance (Peterson, Pietranico, Riepe, \& Xu, 2001; Prather et al., 2004). From the above arguments indicates that there are mixed relationship between fund age and performance based on the management expertise, fund cost and fund size. However, management expertise can be expensive or vulnerable for managing younger mutual funds. In this respect, we are going to test the hypothesis.

\section{$\boldsymbol{H}_{2}$ : Fund age is positively correlated with the performance of the mutual fund.}

\subsection{Management Expertise and Fund Performance}

Investors who are risk averse generally consider PMFs as risk free investment because the rate of return is comparatively low than other stocks. As well as continuation of dividend payment provides comfortable return on investment. Dividend payment and stock price fluctuation are correlated which influenced by the management expertise. Expert managers manage portfolios of mutual funds in such a way that the dividends 
payout can be confirmed as regular basis that leads to quite stable stock price fluctuation (Dewri, Islam, \& Zamman, 2015).

However, funds managed by a team could perform better than the individual manager. As individual managers are not subject to group polarization that limits than to restrict their own thinking and decision. Conversely, panel of decision-makers have adequate access to higher number of alternatives for making a particular decisions that can help to reduce uncertainty in fund performance (Prather, Middelton, \& Cusack, 2001). Moreover, individual fund managers typically manage young and small mutual funds due to simplification of the funds. However, there are different types of organizational diseconomies which lead to diverse forecasts on why small organizations outperform large ones (Chen et al., 2004). The study also assumes that hierarchy costs may be especially relevant for mutual funds performance that can motivate researchers to analyze and test some predictions (Stein, 2002).

Whereas, large funds are quite complex to manage for wider portfolios that requires diverse management expertise (Chen et al., 2004). Public mutual funds in Bangladesh are operating by panel fund managers. These panel managers can bring diseconomies as it is very hard to coincide on a decision during fund operation. In this regard, the study is going to test hypothesis

$\boldsymbol{H}_{3}:$ Fund management expertise is positively correlated with the Performance of the mutual fund.

\section{Methodology}

\subsection{Approach}

This research will conclude about the mutual funds performance based on capital, dividend payout, net operating income and earnings per share. This information can be obtained from Dhaka and Chittagong Stock exchange internal resource, website and respective annual reports. To get this information secondary sources will be applicable. But measuring performance merely not depend on the above variables rather multiple variables. To get the desire output the research will also consider qualitative data.

\subsection{Sample Size}

There are total 43 mutual funds listed in the Dhaka and Chittagong Stock Exchange. These mutual funds are operating by both public and private fund managers. Only 8 mutual funds are operated by the ICB (public). For the research purposes this study consider only public mutual fund manage by the ICB. The remaining mutual funds are not considered as those are different characteristics.

\subsection{Data Analysis}

To conduct the statistical analysis we are considering 15 years day-to-day transaction of 8 public mutual funds listed in Dhaka and Chittagong stock exchange. Therefore the total firm year would 128. It is important to do analysis for better output and decisions with best application.

\subsection{Statistical Technique}

Due to the construction of multiple regressions analysis was used to test the relationships between the variables. The following multiple linear regression model was used to test the hypothesized relationships between constructs in the theory of Mutual fund performance:

$$
\text { Model: } \quad \operatorname{PMFP}=\alpha+\beta F A_{i}+\beta F Z_{i}+\beta R_{i}+\beta D I V_{i}+\beta P / E_{i}+\beta N A V_{i}+\infty
$$

where Mutual Fund Performance (PMFP) is the fund performance of the manager, FA the Fund Age towards fund performance, FZ the Fund size, , R the return, DIV the dividend of the fund, P/E is the price earning ratio of the fund and NAV is the net asset value. 


\section{Analysis and Findings}

\subsection{Descriptive Analysis}

Table 1. Fund size, age and performance of the mutual fund

\begin{tabular}{|c|c|c|c|c|c|c|c|c|c|c|}
\hline Fund name & Fund age & Fund size (BDTm.) & $\begin{array}{l}\text { Ave mkt. } \\
\text { cap } \\
(2000-2015)\end{array}$ & $\begin{array}{l}\text { Mkt } \\
\text { cap1999 }\end{array}$ & Growth & Growth \% & Return & Dividend (\%) & $\mathrm{P} / \mathrm{E}$ & NAV \\
\hline 1 & 35 & 8 & 3546.636 & $1,105.46$ & $2,441.18$ & 220.83 & 216.79 & 402.67 & 13.43 & $2,022.95$ \\
\hline 2 & 31 & 5 & 1160.84 & 408.60 & 752.25 & 184.11 & 76.37 & 168.60 & 11.61 & 506.56 \\
\hline 3 & 30 & 10 & 819.0972 & 346.46 & 472.64 & 136.42 & 56.89 & 123.93 & 10.94 & 431.42 \\
\hline 4 & 29 & 10 & 780.074 & 293.38 & 486.70 & 65.90 & 56.92 & 380.80 & 9.99 & 447.77 \\
\hline 5 & 26 & 15 & 632.4556 & 196.52 & 435.93 & 221.83 & 38.16 & 90.67 & 12.30 & 376.49 \\
\hline 6 & 28 & 50 & 303.1879 & 144.71 & 158.48 & 109.52 & 23.40 & 52.93 & 9.85 & 166.70 \\
\hline 7 & 20 & 30 & 408.7559 & 117.25 & 291.51 & 248.62 & 24.99 & 57.80 & 11.80 & 220.31 \\
\hline 8 & 19 & 50 & 298.7568 & 109.21 & 189.55 & 173.57 & 22.20 & 53.10 & 10.48 & 183.52 \\
\hline
\end{tabular}

Table 1 shows the relationship between public mutual funds size and its related performance over fifteen years. Fund size has positive relationship with fund performance as eighth public mutual fund just operating for 19years with a high degree of growth (174 percent) compare to first (221 percent) in 38 years or second (184 percent) in 31 years. Thus, if the eight PMF operates upto 38 years than its performance would gone up to approximate 348 percent. This indicates that fund size and age has significant impact on fund performance. However, apart from fund age and fund size there might have some other factors that affect the fund performance (See fifth mutual fund). This could happen due to mutual fund management efficiency and diversified portfolio and risk management capacity (Chen et al., 2004). Additionally, fund performance relies on investors motivational factors (return, dividend, $\mathrm{P} / \mathrm{E}$ and NAV). While consistent dividend payout leads to sustainable fund performance than inconsistent dividend payout MF stock.

\subsection{Statistical Analysis}

Table 2. ANOVA table on nav, fund size (bdtm.), p/e, fund age, dividend (\%), return

\begin{tabular}{lllllll}
\hline ANOVA $^{\mathbf{b}}$ & \multicolumn{1}{l}{} & & & \\
\hline Model & & Sum of Squares & df & Mean Square & F & Sig. \\
\hline 1 & Regression & 3904727.291 & 6 & 650787.882 & 37730.376 & $.004^{\text {a }}$ \\
& Residual & 17.248 & 1 & 17.248 & & \\
& Total & 3904744.539 & 7 & & & \\
\hline
\end{tabular}

a. Predictors: (Constant), NAV, Fund size (BDTm.), P/E, Fund age, Dividend (\%), Return.

b. Dependent Variable: Growth.

Table 3. Coefficient table NAV, fund size (BDTm.), P/E, fund age, dividend (\%), return

\begin{tabular}{|c|c|c|c|c|c|c|}
\hline \multicolumn{7}{|c|}{ Coefficients $^{\mathrm{a}}$} \\
\hline & & \multirow{2}{*}{\multicolumn{2}{|c|}{ Unstandardized Coefficients }} & \multirow{2}{*}{\multicolumn{3}{|c|}{$\begin{array}{l}\text { Standardized } \\
\text { Coefficients }\end{array}$}} \\
\hline & & & & & & \\
\hline \multicolumn{2}{|c|}{ Model } & B & Std. Error & Beta & $\mathrm{t}$ & Sig. \\
\hline \multirow[t]{7}{*}{1} & (Constant) & -1599.652 & 82.470 & & -19.397 & .033 \\
\hline & Fund age & 3.140 & .773 & .023 & 4.064 & .154 \\
\hline & Fund size (BDTm.) & 4.608 & .296 & .115 & 15.581 & .041 \\
\hline & Return & 10.480 & .310 & .906 & 33.797 & .019 \\
\hline & Dividend (\%) & .515 & .041 & .100 & 12.632 & .050 \\
\hline & $\mathrm{P} / \mathrm{E}$ & 120.117 & 5.424 & .197 & 22.144 & .029 \\
\hline & NAV & -.098 & .038 & -.080 & -2.560 & .237 \\
\hline
\end{tabular}

a. Dependent Variable: Growth. 


\subsection{Multiple Regression Results}

The results shown in Table 2, reveals an overall adjusted $\mathrm{R}^{2}$ of 1.00 , showing that the independent variables in the model, fund age, fund size, fund return, dividend payout, $\mathrm{P} / \mathrm{e}$ of the fund and fund NAV, account for $100 \%$ of the variation in the dependent variable, fund performance. This relatively high-effect size shows that the constructs hypothesized in the model are good predictors of fund performance. Based on the analysis, the beta coefficients for fund size, fund age and fund management expertise (which reflect on fund dividend payout and growth of Net Asset Value of the fund) were significant at conventional levels, with beta (fund age) $=0.023$ ( $p=$ $0.154)$ and beta $(\mathrm{NAV})=-.80(\mathrm{p}=.237)$ which reflects that fund age and NAV are not significantly related with fund performance. The similar findings also observing across globe in the mutual fund industry (see Ferreira, Miguel and Ramos, 2007). Whereas, with beta (fund size $)=.115(\mathrm{p}=.041)$, beta (return) $=.906(\mathrm{p}=.019)$, beta (dividend $)=.100(\mathrm{p}=.05)$ and beta $(\mathrm{p} / \mathrm{e})=.197(\mathrm{p}=.029)$. These results support H2 and H3, but H1 is not supported. Significance testing was performed to determine if the beta coefficients were statistically different for fund size, fund age and fund management expertise.

\subsection{Findings}

ICB is government owned investment bank in Bangladesh which comprises skilled and experienced professionals and dedicated management team are operating for economic development through capital market investment. Generally, mutual funds have fixed tenure but public mutual funds are open ended. Since operation of mutual fund market, ICB is operating 8 mutual funds till now through capital market. The research attempts to investigate the overall fund performance based on fund age, fund size and management expertise. The study concludes that fund performance is significantly related with fund size, regular basis dividend payout, minimal price earnings ratio and return of the fund. These are also depends on the management expertise as these factors are decided by the individual fund managers. Conversely, the research also indicates that fund age and NAV are insignificant for fund performance.

\section{Conclusion}

This study aims to examine the mutual fund performance in Bangladesh 1999-2005 periods considering 128 firm years for analysis purposes. The study also considers several fund features as latent determinants of fund performance: size, age, return, dividend, P/E ratio and NAV. The results show that funds size, return, dividend payout and $\mathrm{P} / \mathrm{E}$ is positively associated with fund performance. As well as Larger funds achieve higher performance due to significant presence in the capital market and gain economies of scale in the mutual fund industry Bangladesh. However, fund age and NAV is negatively correlated with fund performance indicating that younger funds tend to perform better.

Importantly, this research concludes PMFP by considering few factors such as: size, age, return, dividend, P/E ratio and NAV, where few more factors can be included like: fund operating fees, management structure and tenure, fund information disclosures. In addition, the research could be more robust, if the researchers consider comparing both private and public mutual funds together.

\section{References}

Bauer, R., Koedijk, K., \& Otten, R. (2005). International evidence on ethical mutual fund performance and investment style. Journal of Banking and Finance, 29, 1751-1767. http://dx.doi.org/10.1016/j.jbankfin.2004.06.035

Brennan, M., \& Hughes, P. (1991). Stock prices and the supply of information. Journal of Finance, 46, 1665-1691. http://dx.doi.org/10.1111/j.1540-6261.1991.tb04639.x

Chen, J., Hong, H., Huang, M., \& Kubik, J. D. (2004). Does Fund Size Erode Mutual Fund Performance? The Role of Liquidity and Organization. The American Economic Review, 94(5), 1276-1302. http://dx.doi.org/10.1257/0002828043052277

Ciccotello, C., \& Grant, T. (1996). Equity fund size and growth: Implications for performance and selection. Financial Services Review, 5, 1-12. http://dx.doi.org/10.1016/S1057-0810(96)90023-2

Dewri, L., Islam, Md. R., \& Zamman, S. M. A. (2015). Behavioral analysis of investors' attitude towards dividend declaration in developing country-A case of Bangladesh. International Journal of Business and Management (IJBM), 10(11), 185-198. http://dx.doi.org/10.5539/ijbm.v10n11p185

Ferreira, M., Keswan, A., Miguel, A., \& Ramos, S. (2012). The Determinants of Mutual Fund Performance: A Cross-Country Study. Review of Finance Advance Access, Oxford University Press.

Glosten, L., \& Harris, L. (1988). Estimating the components of the bid-ask spread. Journal of Financial 
Economics, 21, 123-142. http://dx.doi.org/10.1016/0304-405X(88)90034-7

Gregory, A., Matatko, J., \& Luther, R. (1997). Ethical unit trust financial performance: Small company effects and fund size effects. Journal of Business Finance and Accounting, 24, 705-725. http://dx.doi.org/10.1111/1468-5957.00130

Grinblatt, M., Titman, S. (1989). Mutual Fund Performance: An Analysis of Quarterly Portfolio Holdings. The Journal of Business, 62(3), 393-416. http://dx.doi.org/10.1086/296468

Jensen, C. M. (1968). The Performance of Mutual Funds in the period 1945-1964. Journal of Finance, 23(2), 389-416. http://dx.doi.org/10.1111/j.1540-6261.1968.tb00815.x

La, P., Rafael, F. Lopez-de-Silanes, Andrei, S., \& Robert, V. (1997). Legal determinants of external finance. Journal of Finance, 52, 1131-1150. http://dx.doi.org/10.1111/j.1540-6261.1997.tb02727.x

Otten, R., \& Bams, D. (2002). European Mutual Fund Performance. European Financial Management, 8(1), 75-101. http://dx.doi.org/10.1111/1468-036X.00177

Peterson, J., Pietranico, P., Riepe, M., \& Xu, F. (2001). Explaining the performance of domestic equity mutual funds. Journal of Investing, 10, 81-92. http://dx.doi.org/10.3905/joi.2001.319477

Prather, L., Bertin, W., \& Henker, T. (2004). Mutual fund charateristics, managerial attributes and fund performance. Review of Financial Economics, 13, 305-326. http://dx.doi.org/10.1016/j.rfe.2003.11.002

Prather, L., Middelton, K., \& Cusack, A. (2001). Are N+1 heads better than one? The timing and selecting of australian-managed investment funds. Pacific-Basin Finance Journal, 9, 379-400. http://dx.doi.org/10.1016/S0927-538X(01)00021-X

Roger, L. (1997). Buffett: The Making of an American Capitalist. Orion publisher.

Stein, J. (2002). Information production and capital allocation: Decentralized versus hierarchical firms. Journal of Finance, 57, 1891-1921. http://dx.doi.org/10.1111/0022-1082.00483

\section{Copyrights}

Copyright for this article is retained by the author(s), with first publication rights granted to the journal.

This is an open-access article distributed under the terms and conditions of the Creative Commons Attribution license (http://creativecommons.org/licenses/by/3.0/). 